\title{
A PERDA E A RETOMADA DO GUATÓ
}

\author{
Kristina BALYKOVA (D) \\ Universidade do Texas em Austin (UT) \\ Gustavo GODOY (D) \\ Universidade Federal do Rio de Janeiro (UFRJ)
}

\section{ఠ}

OPEN ACCESS

EDITADO POR

- Marcus Maia (UFRJ)

- Bruna Franchetto (UFRJ)

REVISADO POR

- Denny Moore (MPEG)

- Kristine Stenzel (UFRJ)

\section{SOBRE OS AUTORES}

- Gustavo Godoy

Conceptualização, Administração de

Projeto, Investigação, Visualização,

Escrita - Rascunho Original e Escrita

- Análise e Edição.

- Kristina Balykova

Conceptualização, Administração de

Projeto, Investigação, Visualização,

Escrita - Rascunho Original e Escrita

- Análise e Edição.

DATAS

- Recebido: 20/05/2020

- Aceito: 07/10/2020

- Publicado: 26/11/2020

COMO CITAR

BALYKOVA, Kristina; GODOY, Gustavo. (2020). A perda e a retomada do

Guató. Cadernos de Linguística, v. 1, n.

3, p. 01-15.
RESUMO

O guató é uma língua indígena seriamente ameaçada cujo povo habita o Pantanal desde tempos imemoriais. Para entender como se deu a obsolescência desta língua, apresentamos três processos que levaram à desestruturação da família guató: o celibato masculino, o casamento feminino com neobrasileiros e o apadrinhamento/apropriação de crianças por fazendeiros. Para tanto, relatamos e comentamos entrevistas dadas por Guató sobre como a língua deixou de ser utilizada em suas famílias. Como o povo guató apresentava um padrão de assentamento dispersivo e uma atomização de famílias, estes três processos (concomitantes e que afetaram de formas específicas diferentes famílias) contribuíram para a degradação dos liames que sustentavam o idioma guató. Junto com determinantes sociais e demográficos que não analisamos mais detidamente - como epidemias, desproteção econômica e falta de identificação oficial - a desestruturação familiar levou ao fim do antigo modo guató de habitar o Pantanal e de sua língua, que agora sobrevive como memória de alguns idosos e, de maneira mais restrita, no ambiente escolar e em tentativas de revitalização.

\section{ABSTRACT}

Guató is a highly endangered indigenous language of a people who have inhabited the Pantanal since time immemorial. To understand how the obsolescence of this language took place, we present three processes that 
resulted in the disintegration of Guató families: male celibacy, marriages between Guató women and Brazilian men, and the appropriation of Guató children by fazenda owners. For that purpose, we offer and comment on interviews given by Guatós about how the language fell into disuse in their families. Since the Guató people were characterized by a dispersive settlement pattern and an atomization of families, these three processes (which coexisted and affected different families in specific ways) contributed to the degradation of bonds that sustained the Guató language. Along with social and demographic determinants that we do not analyze closely here, such as epidemics, economic fragility, and lack of official identification, the disintegration of families brought to an end the ancient Guató way of living in the Pantanal as well as their language, which now remains only in the memory of some elderly people and, in a more limited way, in the school environment and in revitalization attempts.

\section{PALAVRAS-CHAVE}

Guató; Línguas Ameaçadas; Morte Linguística; Revitalização.

\section{KEYWORDS}

Guató; Endangered Languages; Language Death; Revitalization. 


\section{INTRODUÇÃO}

O guató é uma língua virtualmente extinta, não é falada como primeira língua por nenhum jovem nem é usada em conversas cotidianas. Entretanto, ela ainda existe: alguns idosos a lembram com diferentes competências. Os mais competentes, capazes de contar histórias na língua, são Vicente da Silva e Eufrásia Ferreira, ambos com mais de 70 anos.

O território tradicional guató se estendia por beiras dos rios Paraguai e São Lourenço. É uma região próxima e, em alguns pontos, contígua à fronteira com a Bolívia. No passado, uma parte dos Guató foi assimilada aos Chiquitano bolivianos por missioneiros (MONTAÑO ARAGÓN, 1987 apud CREVELS; MUYSKEN 2009, p. 19). A atual aldeia Uberaba da Terra Indígena (TI) Guató fica em frente ao município boliviano Puerto Quijarro, separada deste por uma baía. Alguns dos atuais moradores da TI Guató já residiram do lado oposto, mas não conhecemos nenhum Guató que esteja na Bolívia atualmente.

Duas TIs são ocupadas pela etnia: TI Guató, em Mato Grosso do Sul, e TI Baía dos Guató, em Mato Grosso. Além disso, vários Guató residem em outras locais, como nas cidades de Corumbá, Cáceres, Poconé e Campo Grande. Os próprios falantes mais competentes entram nesse grupo: Eufrásia Ferreira é moradora de Corumbá, enquanto Vicente da Silva vive sozinho na barra do rio São Lourenço, na divisa entre os dois Matos Grossos.

Há 40-50 anos, a ilha Ínsua, mais tarde transformada na TI Guató, ainda abrigava um número considerável de Guató proficientes na língua nativa. Hoje em dia, registros do conhecimento desses falantes já falecidos embasam a matéria de Língua Étnica, ensinada na escola da TI Guató. Já na TI Baía dos Guató, mais recente, a memória da língua se perdeu completamente. Lá, o resgate começou a ser feito por meio de ações pontuais de revitalização, em três oficinas lecionadas em 2016, 2017 e 2018.

Os autores deste artigo trabalham com o guató desde 2016, no intuito de documentar, descrever e revitalizar a língua. Um quarto objetivo é entender a história da morte da língua. Neste artigo, nos focaremos neste último objetivo: a partir de trajetórias familiares de alguns Guató, relataremos o esfacelamento da comunidade de fala, que tornou o idioma moribundo. Buscaremos conectar os dados de fontes históricas e de trabalhos acadêmicos com os relatos pessoais coletados em entrevistas desde 2018. Para finalizar, trataremos dos modos pelos quais a língua guató ainda persiste no ambiente escolar e em iniciativas de revitalização.

\section{MODO DE VIDA TRADICIONAL GUATÓ}

Os Guató, habitantes do Pantanal desde tempos imemoriais, foram chamados de canoeiros pelo seu modo de vida aquático. Permaneceram com autonomia relativa desde o primeiro 
contato no século XVI até o século XX. Não se desintegraram com o impacto dos espanhóis e guaranis vindos de Assunção, nem com as missões nas áreas adjacentes, nem com a chegada de monçoeiros paulistas. Ainda passaram por outras provações, como epidemias e a Guerra da Tríplice Aliança contra o Paraguai.

O modo de vida tradicional dos Guató foi associado à dispersão e à sazonalidade das águas (FERREIRA, 1848). Os Guató não fundavam "aldeias" e levavam uma vida de pesca e caça. Construíam moradas simples, chamadas em português de beira-o-chão, com apenas uma água de telhado trançado de acuri ou feito de couro de caça. Suas casas ficavam dispersas na beira do rio durante a seca.

$\mathrm{Na}$ época da cheia, buscavam os locais secos para se instalarem: terras mais altas como beiras de morros e aterros, plataformas construídas para se proteger na inundação. Nestes pontos cultivavam alguma plantação. Durante a cheia, diferentes famílias poderiam coabitar para, quando as águas baixassem, espalharem-se novamente.

Os filhos saíam cedo do poder dos pais para criarem suas próprias famílias. Por isso, as famílias rapidamente se dividiam quando os filhos cresciam. Sobre a coesão social dos Guató, Castelnau (1949, p. 312) observou o seguinte:

\footnotetext{
Os Guatós apresentam exemplo raro de um povo sem nenhum liame nacional e que nunca se concentra em povoados; cada família leva vida isolada e constrói a sua moradia nos lugares mais inacessíveis. No meio de vastos pantanais ou de terras inundadas, avista-se uma pequena clareira em plena mata. Ali, sob o tosco barracão, instala o Guató a sua morada; por mobiliário apenas algumas cabaças e peles de onça, animal que abunda na região e é alvo de encarniçada guerra.
}

Este era o modo de ocupação guató, em que as famílias tendiam a se cindir e se reuniam esporadicamente. A organização dos encontros periódicos cabia aos capitães nomeados pelo governo segundo a escolha dos próprios Guató (SCHMIDT, 1905, p. 312-313). O povo guató, portanto, não formava assentamentos nucleados, com casas próximas umas das outras. O núcleo da preservação da língua guató eram suas microcomunidades de fala, famílias espalhadas e dispersivas.

A desintegração da família guató se deu por várias razões. Além das epidemias que assolaram os povos indígenas, a pressão da sociedade colonizadora se traduziu em três processos sociais que levaram a família e a língua ao desaparecimento. Esses processos são o casamento feminino extraétnico, o apadrinhamento de crianças e o celibato masculino. A seguir, examinaremos cada um deles em detalhes.

\section{CELIBATO MASCULINO ENTRE OS GUATÓ}

No século XIX, os homens guató eram noticiados como polígamos. Como afirmava o diretorgeral dos índios de Mato Grosso, Joaquim Alves Ferreira, "não é raro ver um Guató com 
cinco ou seis canoas cheias de suas mulheres e filhos; contudo o mais ordinário é terem só duas mulheres e mesmo alguns contentam-se com uma" (FERREIRA, 1848).

Porém, já no final do século XIX, a situação havia se mudado completamente. Koslowsky (1895, p. 227) comenta sobre "escassez de exemplares do sexo feminino" entre os Guató, causada pela devastadora epidemia de varíola durante a guerra do Paraguai. Todos os homens guató que o etnógrafo Max Schmidt encontrou em 1901 eram monógamos (SCHMIDT 1905, p. 316). Alguns anos depois, durante sua viagem pelo rio Caracará em 1910, Max Schmidt encontrou um grupo de cinco homens guató solteiros. Segundo a explicação do seu guia, o chefe guató Caetano, "nem de longe todos os Guató homens possuíam mulheres" na época (SCHMIDT, 1912, p. 136).

O celibato involuntário dos homens guató foi se tornando cada vez mais comum ao longo do século $\mathrm{XX}$, em grande parte, porque as mulheres guató preferiam se casar com neobrasileiros, como veremos na seção seguinte. Os filhos do próprio chefe Caetano, Veridiano e José, nunca se casaram. Como apontam Neto, Gutman \& Pereira (1991, p. 12) sobre os dois irmãos, "chamou-nos a atenção o fato desses Guató serem celibatários. Alegaram que a questão está na dificuldade de conseguirem esposas na região. São ambos Guató puros, com perfeito domínio da língua".

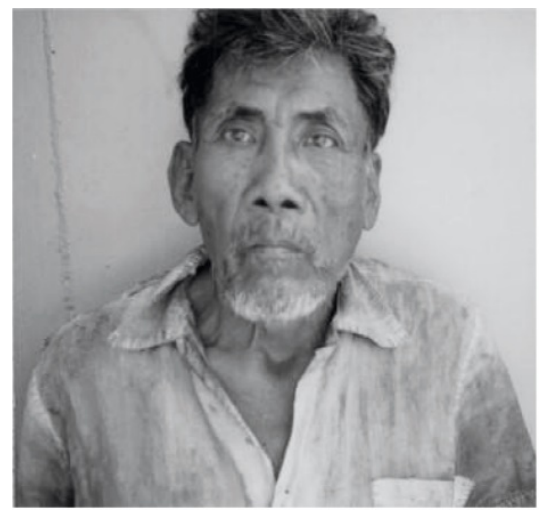

Figura 1. José Caetano. Fonte: Azanha 1991

Outro exemplo são os irmãos de Eufrásia Ferreira, nossa consultora. Eram quatro José, Hemiliano, Polinário, Cipriano - e todos morreram solteiros. 


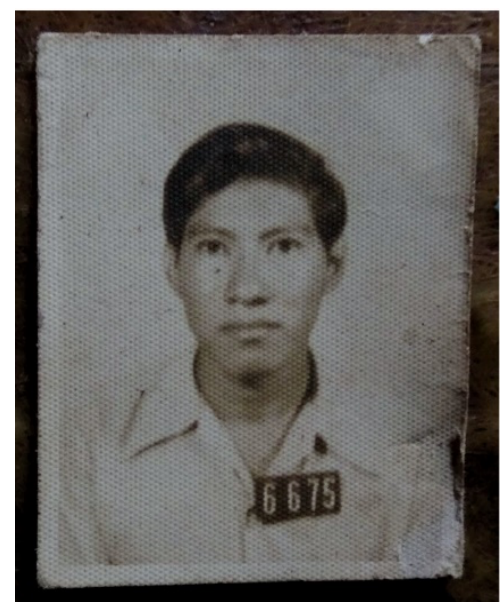

Figura 2. Cipriano, irmão de Eufrásia Ferreira. Fonte: acervo pessoal de Eufrásia Ferreira.

A linguista Adair Palácio (1978, p. 7) explicava essa condição dos homens guató pelo desânimo geral e vício em álcool, que os levassem a uma "auto-eliminação". Outro fator foi a dispersão dos jovens guató, tanto homens como mulheres, em busca de empregos. Assim, aqueles que permaneciam nos locais tradicionais não encontravam pessoas da mesma etnia para se casar. Além disso, as moças guató conseguiam achar maridos em ambientes novos, entre os neobrasileiros, já os homens tinham mais dificuldades nessa questão:

\footnotetext{
Muitos chefes de família não sabem onde estão e o que fazem muitos de seus filhos, principalmente os homens (alegam que os filhos não têm meios para os visitarem na ilha). O resultado é que não ocorreu nenhum casamento na ilha nos últimos 10 anos. Manoel Dinho, por exemplo, perdeu sua mulher há 5 anos; ele mesmo reconhece que jamais arrumará outra. Os dois irmãos Guató que residem no morro Caracará [Veridiano e José] nunca se casaram; dizem que as muIheres Guató "acabaram" (casando-se com brasileiros) e as brasileiras não os querem (por serem "bugres"). (AZANHA 1991, p. 12)
}

O nosso consultor Vicente da Silva, sobrinho de José Caetano por parte da mãe, também não conseguiu construir uma família em que pudesse transmitir a língua nativa à geração nova. Ele até chegou a se casar com uma não Guató, mas a mulher o abandonou enquanto estava grávida.

\section{CASAMENTOS ENTRE MULHERES GUATÓ E HOMENS NEOBRASILEIROS}

Contrapondo as mulheres guató aos homens, Palácio (1978, p. 7) afirma que elas "parecem mais animadas, partem para casamentos com não Guatós, provocando a perda do vínculo linguístico". Segundo Cruvinel (1978, p. 7-8), que recenseou uma parte da população guató nos locais de ocupação tradicional, quatro dos seis domicílios tinham como o chefe um homem neobrasileiro casado com uma mulher guató. Tais casamentos interétnicos são 
noticiados desde o início do século XX, quando Schmidt (1905, p. 306) registra que "várias mulheres [guató] vivem fora da área guató autêntica junto com homens brasileiros".

Nesta seção, apresentaremos histórias de três mulheres guató casadas com neobrasileiros (mesmo que alguns sejam de origem indígena). As histórias foram contadas por seus filhos, hoje todos idosos. Nos três casos, os filhos nunca aprenderam a conversar na língua indígena, devido à repressão por parte dos pais.

Alfredo de Assunção Silva (72 anos) é morador da TI Guató, filho de uma Guató com um neobrasileiro. Segundo Alfredo, seu pai tinha algum sangue indígena ("papai era índio, mas de muito longe") 1 . Alfredo nos informou com orgulho tanto seu nome oficial, no qual conseguiu reunir os sobrenomes do pai e da mãe, quanto seu nome indígena, [motábu], que significa 'cágado'.

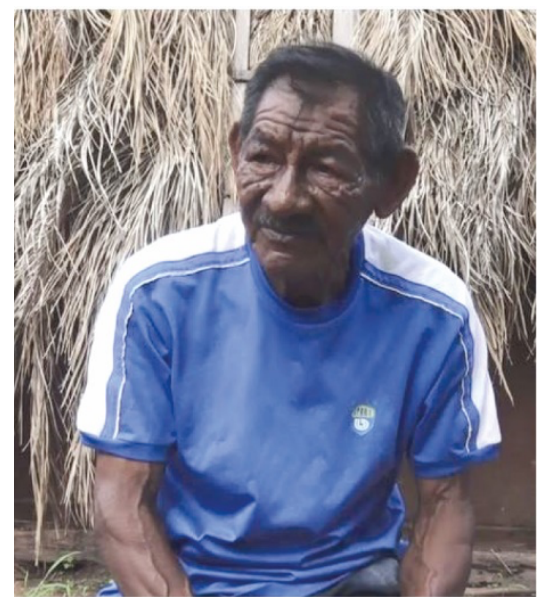

Figura 3. Alfredo de Assunção Silva, TI Guató, 14/01/2018. Fonte: acervo dos autores.

Quando reencontrou sua prima Eufrásia Ferreira no início de 2018, após mais de 40 anos, Alfredo ficou muito entusiasmado em saber que ela ainda falava guató. Disse que Eufrásia deveria ensinar o idioma a ele e aos outros que têm sangue guató, pois eles aprenderiam mais rápido do que outras pessoas.

O próprio Alfredo domina algumas dezenas de palavras na língua materna, mas nunca aprendeu a conversar. Sua mãe, finada Zulmira da Silva, era falante nativa do guató. Inclusive, foi seu marido, Antônio Assunção, que lhe ensinou a falar em português, mas o contrário não aconteceu. Como explicou Alfredo, "ela não procurou ensinar ele [a língua guató], e nem ele queria saber". Quando perguntamos o que seu pai achava da língua indígena, Alfredo evitou responder: 
Eu não sei não, eu não posso explicar, porque o pai da gente... mãe, a gente sempre tá juntinho né, mas pai pera lá, não vai encostar igual a gente encosta na mãe, mãe tudo é carinhoso, tudo é cheio de jeito né, mas pai não, o carinho dele é sério, e gente tem que entender também o carinho do pai.

Segundo Eufrásia, o marido de Zulmira ficava aborrecido quando ouvia a mulher conversar em guató, pois achava que ela estava o xingando ou falando de outro homem: "se não parasse, ia largar murro nela". Certamente, foi por isso que os filhos nunca dominaram guató com fluência, embora todos conheçam algumas palavras na língua. Alfredo nos contou que aprendeu as coisas que sabe já adulto e às escondidas:

Depois de criado, quando ninguém 'tava aí, aí eu perguntava como que o nome na idioma, aí ela [a mãe] falava, ensinava a gente, por isso que algumas palavras sei, por causa disso.

A história da Guató Zulmira, tia paterna da nossa consultora Eufrásia Ferreira, tem bastante em comum com a história da Guató Maria Erotilde, tia materna de Eufrásia. Maria Erotilde foi casada com um cearense chamado Antônio, quase 50 anos mais velho do que ela. Uma das suas filhas é Jaci da Costa (65 anos), que cresceu na ilha Ínsua, mas reside em Corumbá há muitos anos. Jaci nos contou sobre sua infância na ilha e sua relação com a língua guató.

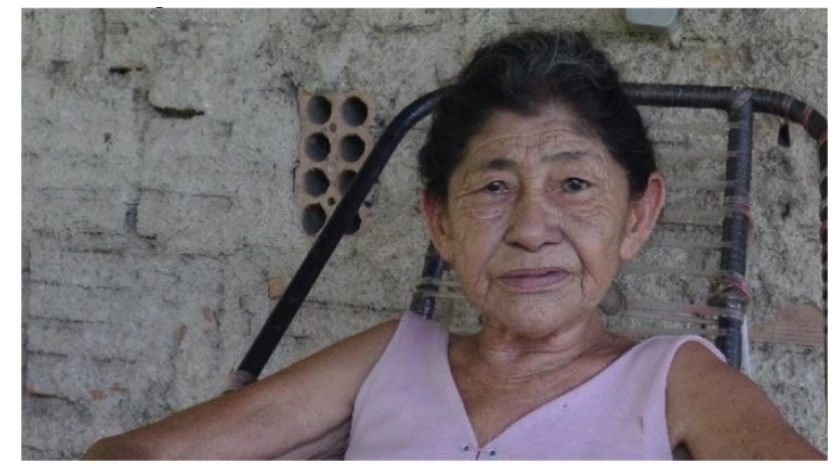

Figura 4. Jaci da Costa, Corumbá, 18/01/2018. Fonte: acervo dos autores.

A mãe de Jaci, Maria Erotilde, era fluente em guató e falava português "tudo atrapaIhado". Naquela época, na ilha Ínsua ainda viviam alguns falantes ativos do guató, principalmente mulheres. Francolina, conhecida como a dona Negrinha, Josefina e Estelita se reuniam na casa de Maria Erotilde para tomar mate. Contudo, passavam a conversar em guató somente quando Antônio, marido de Maria Erotilde, saía de casa:

\footnotetext{
Minha mãe ajuntava com tia Zefina [...] a gente ria deles, porque meu pai não gostava que mamãe ensinava a gente pra falar essas coisas, porque diz que era língua de bugre, papai falava assim: "Que que vai ensinar essas crianças falar língua de bugre, eles não vão falar português". Ele [o pai] ria de mamãe por causa da língua, porque ele não sabia falar né, ele ria de mamãe quando falava com as turma dela [...] então ele falava: "Eles 'tão até me xingando".
} 
Quando criança, Jaci chegou a entender um pouco do guató, pois cuidava de sua avó, que se comunicava só no idioma. Infelizmente, a avó morreu quando Jaci ainda era menina. Além disso, ela nos confessou que "não fazia também caso, porque criança já não faz caso de nada né." Dessa maneira, hoje em dia, Jaci só se lembra de duas palavras em guató: matãgi 'cigarro' e mokw̃́ ‘bugio'.

O terceiro caso foi relatado por Dolores Ramos dos Santos (97 anos), comadre da nossa consultora Eufrásia Ferreira. Dolores, cujo nome na língua é [baǒthế], é filha de uma Guató com um carioca.

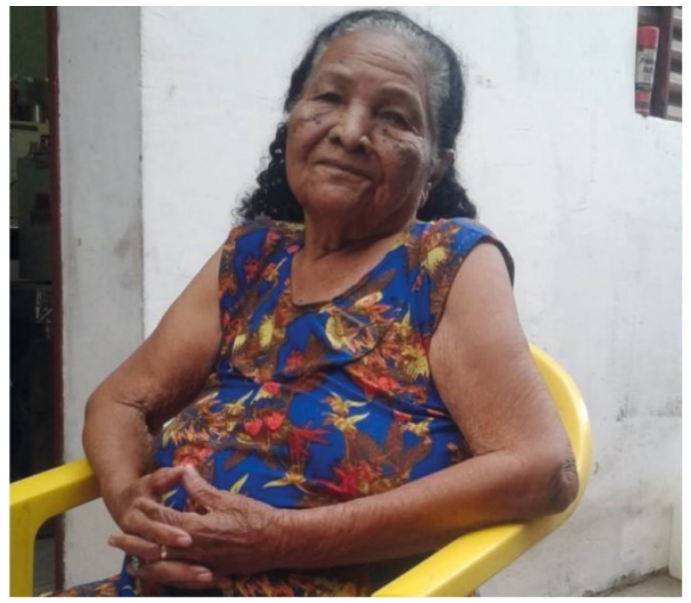

Figura 5. Dolores Ramos dos Santos, Corumbá, 31/07/2018. Fonte: acervo dos autores.

O pai de Dolores, Augusto, proibia o uso da língua guató em casa. Conforme lembra Dolores, "se chegava o pessoal de mamãe e cumprimentava no idioma, ela tinha que responder em português por causa de papai." Após a mãe de Dolores, Carolina, avisar os parentes, eles passaram a cumprimentá-la em português.

Assim como os outros homens que não dominavam a língua indígena, Augusto achava que a esposa aproveitasse as conversas em guató para falar mal dele. Carolina conversava em guató com os filhos, Dolores e Sebastião, só quando o marido saía, pois ele "era um carioca ciumento".

Dolores chegou a ter uma competência passiva no guató, entendendo o idioma. Até hoje, se lembra de algumas palavras, principalmente nomes de animais. O seu irmão Sebastião foi bem mais competente no guató do que ela. Contrariando o seu pai, o menino dizia que ia pescar, mas fugia para a aldeia do avô guató. Lá passava o dia, brincando, caçando e pescando com os parentes da mãe. Aprendeu a conversar no idioma tanto que parecia ser da aldeia. Ele foi morto em uma fazenda, sem ter passado a língua guató para filhos. 


\section{CRIANÇAS GUATÓ CATIVAS}

No início do século passado, Monoyer (1905, p. 156) relatava que, enquanto os adultos guató se recusavam a trabalhar em fazendas, crianças guató foram "recolhidas nestes estabelecimentos e criadas desde a mais tenra infância". Eram mantidas como cativas nas fazendas, para trabalharem de guias e peões, servindo de cavaleiros e manejando o laço. As crianças entregues a fazendeiros esqueciam a língua indígena, passando a conversar somente em português.

Esse costume violento persistiu durante o século XX. Palácio (1978, p. 7) nota que "tem sido prática naquela área tomar as crianças de seus pais índios para criá-las nas grandes fazendas onde se tornam falantes exclusivos do português". Uma exceção citada pela linguista é o caso de Francolina Rondon, uma das últimas falantes fluentes do guató, que com 7 anos fugiu de uma fazenda, voltando a conviver com sua mãe e avó. O Guató Júlio César Pereira de Freitas comenta sobre a denominação "bugrinhas de estimação" para as meninas índias que eram levadas como cativas (FREITAS, 2010).

$\mathrm{Na}$ TI Guató, conhecemos Cecília de Souza (76 anos), que foi uma dessas crianças cativas. Ela nos contou sobre a ruptura que os anos na fazenda produziram na sua vida, afastando-a para sempre da família e apagando seu conhecimento da língua nativa.

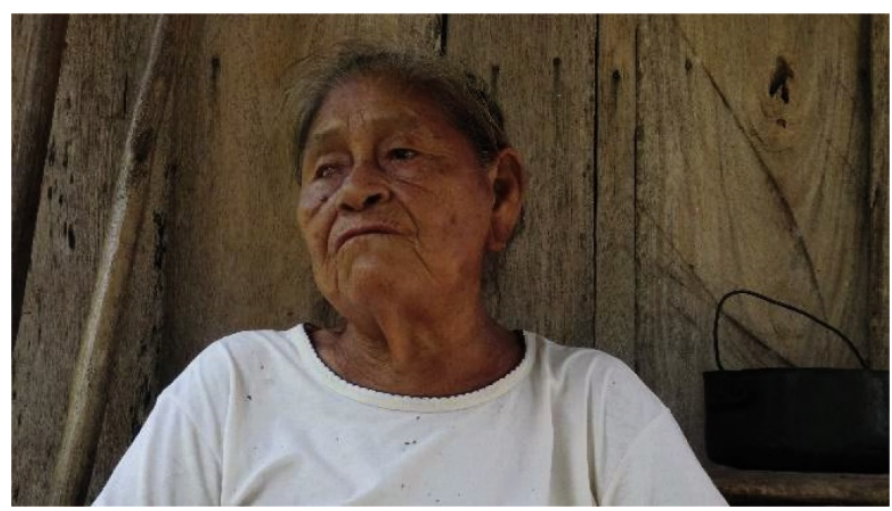

Figura 6. Cecília de Souza, TI Guató, 13/01/2018. Fonte: acervo dos autores

Cecília, nascida em uma família guató, tinha apenas 4 ou 5 anos de idade quando foi retirada do seio familiar. Otávio, seu irmão mais velho, a levou para ser criada na fazenda. Cecília, que não falava nem entendia o português, tentou resistir à mudança:

Eu não queria ir. Puxa! Mas aí eu falei pra meu irmão na língua né que eu não queria ir. Comecei a chorar, e ele conversou comigo, na idioma né. Eu não queria de jeito [nenhum ir], eu queria voltar com ele lá. "Não, eu quero minha mãe" - falei, "Eu quero ela". Aí ele conversou, conversou, conversou, falou assim: "Você vai lá, daqui a três dias eu vou lá ver você". [...] Falei: "Quá! Eu não vou, não vou de jeito nenhum”. Aí, ele embarcou eu na canoa, caí n'água! Eu queria era escapar dele [do irmão]. [...] Eu ficava triste né, por causa não sabia onde que eu ia parar né. 
Otávio voltou à fazenda somente depois de um ano. Nesse meio tempo, Cecília tentou fugir novamente ("Um dia eu achei o portão aberto, saí pra ir embora. Mas custaram me achar!"). Por fim, acabou se resignando à situação de cativa da fazenda. Até então monolíngue em guató, a menina demorou para começar a falar em português. Os donos da fazenda até desconfiaram que ela fosse muda:

\begin{abstract}
Aí, fui acostumando, a menina brincava comigo e tudo, só que eu não falava em português, falavam comigo, eu não falava nada. Aí, ainda minha madrinha falou: "Eu acho que ela é muda, porque ela não fala nada né" [...] Aí um dia ela falou assim: "Abre sua boca aí! [...] vamos ver se não tem uma coisa, problema na língua, essas coisas". Aí, eu abri minha boca. "Tira sua língua! Não tem nada! É porque não fala mesmo né. É encravada, ele não fala mesmo, é braba”.
\end{abstract}

Cecília passou os primeiros anos na fazenda brincando com a filha da patroa e realizando serviços simples, como varrer a casa. Mas, assim que a menina cresceu um pouco, a dona da fazenda deixou evidente para que quis criá-la, obrigando Cecília a trabalhos pesados e sujeitando-a a castigos físicos: "Depois que eu peguei um tamanho, que já sabia fazer as coisas, trabalhar, aí que ela [a patroa] já foi pondo eu nas coisas de... poxa! Lavar roupa, engomar roupa e chicote também".

Na fazenda, Cecília não era a única criança pega para ser mão de obra cativa. Além dela, lá estavam uma prima sua, que também acabou esquecendo a língua guató, e uma menina de Poconé. Cecília afirmou que o caso dela fazia parte de uma prática comum:

Naquela época, filho dos outros criavam assim, pegavam pra criar desse jeito né [...] trabalhava como não sei o quê, sem ganhar, ganhava apena era só uma sandalinha no pé e um vestidinho pra vestir né, e pronto... e 'guentar chicote também. Minhas irmãs mesmo, nenhum foi criado com minha mãe. Até um pontinho que já aguentava andar, já ia na mão desses povo.

Cecília só parou de sofrer os maus tratos quando se casou. Quando deixou a fazenda junto com o marido, Cecília reencontrou o irmão Otávio, mas já não era capaz de conversar com ele na língua nativa. Então, o irmão tentou fazer com que ela se lembrasse do guató, falando frases na língua e traduzindo-as para o português, mas o encontro foi breve demais para que o conhecimento pudesse ser recuperado:

\footnotetext{
[Meu irmão] ia lá pra falar comigo, pra ver se eu tornava outra vez né, voltar na idioma, mas foi poucos dia, terminou o serviço dele [do marido] lá e descemos pra baixo [...]

Ele [o irmão Otávio] falou: "Guarda bem, grava bem na sua ideia aí, assim você vai voltar falando [...] Tem que voltar, né, minha irmã, tem que nos falar, nem que você num fala assim completo como era, mas você sabendo algumas palavras, já vê que você é Guató né, que você é índia".
}

Quando se mudou para a TI Guató, Cecília tentou reaprender algo da língua nativa com o morador Pedro Rodrigues, mas este falava baixinho e não gostava de repetir. Impaciente, reclamava da aluna: "Não põe sentido!". 
Desde que foi levada à fazenda, Cecília nunca mais viu os pais. Não tem notícias dos irmãos, exceto uma irmã mais nova, que mora em Corumbá, mas as duas não se veem há muito tempo.

\section{RETOMADA DA LÍNGUA GUATÓ}

Nas seções anteriores, mencionamos várias vezes a TI Guató. É o local onde, ainda antes do reconhecimento oficial, havia uma comunidade de falantes da língua guató e onde alguns deles residiram até falecer. Por isso, lá a memória da língua indígena ainda é viva. Em particular, a esposa do ex-cacique, Dalva Maria de Souza Ferreira, registrou centenas de palavras e frases em guató junto a alguns falantes de quem cuidava. O material coletado por ela serve de base para as aulas de Língua Étnica na Escola Estadual Indígena João Quirino de Carvalho - Toghopanãa, na TI Guató. Nessas aulas, os alunos aprendem substantivos (por exemplo, nomes de animais), numerais e frases exortativas, como "vamos comer" ou "vamos tomar café" na língua indígena. É um conhecimento compartilhado por uma boa parte das crianças e dos adultos moradores da TI.
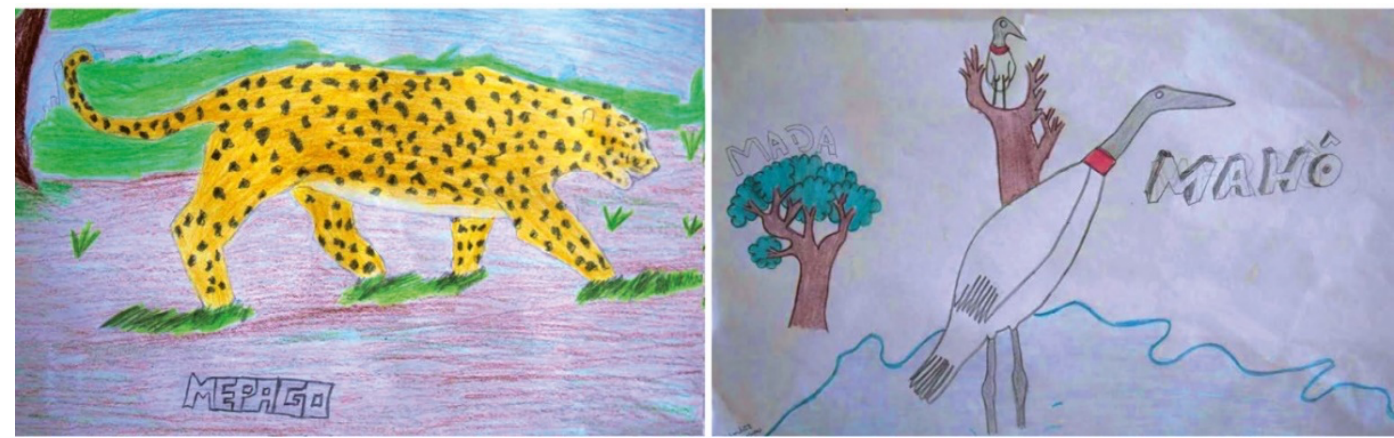

Figura 7. Desenhos feitos por alunos da Escola Estadual Indígena João Quirino de Carvalho - Toghopanãa em aulas de Língua Étnica. Fonte: acervo dos autores.

Os professores de Língua Étnica nos relataram que a grande dificuldade está no ensino da gramática guató, pois não existem materiais didáticos que tratem desse assunto. Assim, a comunidade não consegue passar para o próximo nível do domínio da língua, que é formar frases e fazer pequenos diálogos. Em vista disso, realizamos uma rápida oficina sobre alguns tópicos da gramática guató para poucos professores da TI Guató em 2017. Apesar disto, a formação foi muito inicial, sendo necessária a formulação de cursos mais longos e de materiais didáticos para o guató.

Na TI Baía dos Guató, a memória da língua é quase ausente. O único morador que seria competente no guató, Domingos Manoel de Amorim, está muito debilitado, tendo perdido, inclusive, a fala, em virtude de perda de audição senil. Durante a última década, os Guató 
dessa TI têm reivindicado a criação de uma escola e o resgate da língua ancestral. Em resposta a essa demanda, uma equipe da UFRJ, incluindo os autores deste artigo, realizou três oficinas de revitalização na TI Baía dos Guató.
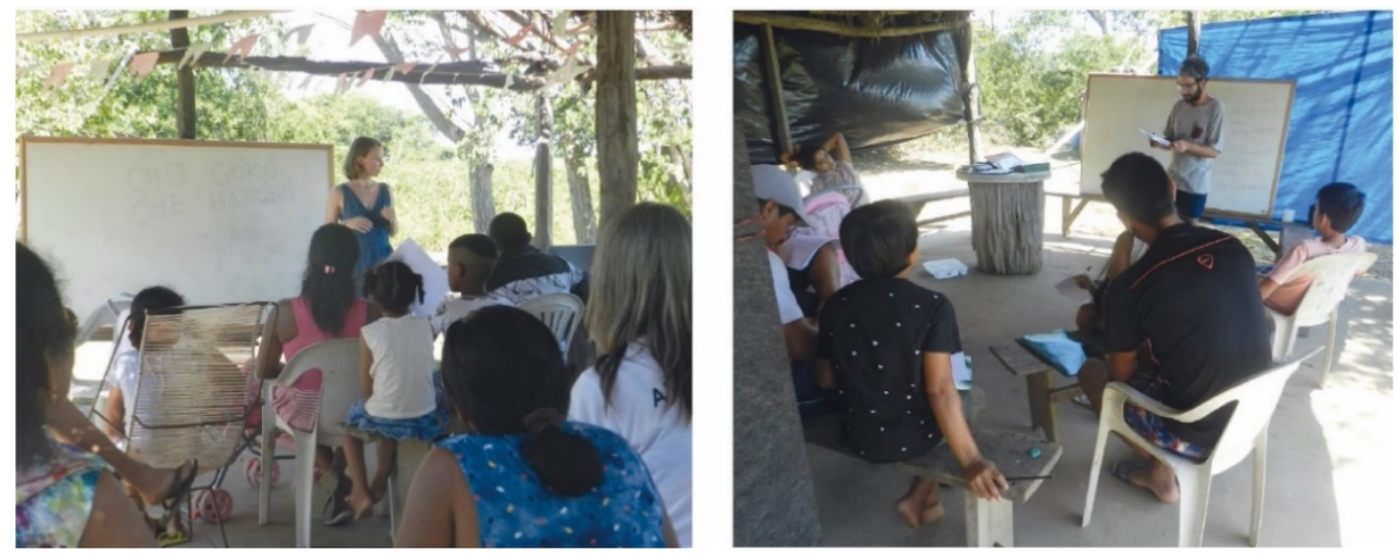

Figura 8. Oficina de revitalização, dezembro de 2018, TI Baía dos Guató. Fonte: acervo dos autores.

A primeira oficina, conduzida em 2016, foi relatada em Franchetto \& Godoy (2017). Após esta oficina, ainda realizamos outras duas, em 2017 e 2018. ${ }^{2}$ O material utilizado nas oficinas de 2016 e 2017 consistia em listas de palavras divididas em campos semânticos (animais, alimentos, partes do corpo etc.) e algumas frases simples. Esse material foi baseado quase exclusivamente nos dados publicados por Palácio (1984), a única descrição geral da língua até agora. Apesar de importante, a tese de Palácio tem suas limitações: vários exemplos são apenas sentenças cortadas ou até palavras incompletas, e argumentações que expliquem a escolha de nomenclatura gramatical são inexistentes. Portanto, esse trabalho não poderia embasar iniciativas de revitalização mais avançadas, tanto pela escassez dos dados linguísticos como pela incompletude e pouca clareza da descrição.

Desde 2016, realizamos trabalhos de campo a fim de compor um acervo da língua guató. Esta documentação já contribuiu para a reanalise de aspectos gramaticais descritos em Palácio (1984), para a descrição de construções novas e para o registro de textos (como histórias pessoais e mitos) na língua. A oficina de 2018 foi baseada nesse material inédito. Novos conhecimentos sobre a predicação nominal nos permitiram a apresentar frases do tipo "Eu sou índio" e "Você é branco" aos Guató. Além disso, lemos com eles uma versão simplificada da história sobre o sequestro de uma mulher por um guariba, contada pela consultora Eufrásia Ferreira e analisada mais tarde em Balykova e Godoy (2019). Atualmente, no âmbito do Projeto de Documentação de Línguas Indígenas (Prodoclin)3, 
estamos a caminho de produzir um dicionário multimídia português - guató, de 600 entradas, que poderá ser usado nas escolas guató. No entanto, falta ainda desenvolver um plano de ação mais sistemático e detalhado, sustentado por materiais didáticos diversos e de qualidade, para que os esforços de revitalização tenham mais eficácia.

\section{CONCLUSÃO}

Como destaca o antropólogo Cardoso (1985, p. 2), "o aldeamento nunca foi a projeção espacial da organização social guató. [...] A unidade social básica de ocupação territorial guató sempre foi a família nuclear. Daí o fato de sempre ter sido o território habitado pelos guatós uma extensa área ocupada por famílias nucleares". Dessa maneira, cada família guató constituía um pequeno reduto em que a língua indígena era preservada e passada adiante.

Entretanto, essa estrutura social não resistiu ao avanço da sociedade colonizadora. As diferentes famílias guató passaram por uma tripla fissão em seu átomo, composto de um casal e seus filhos. Primeiro, os homens guató não conseguiam encontrar esposas. Relegados a um celibato involuntário, não criaram filhos que poderiam ser uma nova geração de usuários do guató. Destes, três homens foram os derradeiros mantenedores do uso cotidiano do guató. Vicente da Silva, nosso consultor, permaneceu junto de sua mãe, Júlia, até sua morte. Já seus tios maternos, Veridiano e José, viviam juntos, utilizando o guató diariamente.

A segunda fissão se referiu às mulheres guató casadas com neobrasileiros, que proibiam o uso da língua indígena. Como resultado, uma geração de filhos quase não teve conhecimento do guató. Nesta geração, sobraram fragmentos de lembranças de um idioma que nunca foi totalmente desenvolvido, memórias escassas da língua falada pelas avós e pelas mães. As próprias esposas dos neobrasileiros, depois de terem usado o português por muitos anos, passaram a esquecer o guató, pois seus interlocutores foram morrendo.

Por fim, as crianças expropriadas de suas famílias foram a terceira fissão. Utilizadas como mão de obra gratuita nas fazendas, elas substituíram o idioma que era de seus antepassados pela língua adventícia na qual recebiam comandos e ordens.

Além disso, houve as epidemias que assolaram a população, como o sarampo e a gripe espanhola. O grupo foi considerado extinto a partir da década de 1940 e, portanto, passou décadas sem ter seus direitos assegurados. Em particular, seus direitos territoriais foram constantemente violados por fazendas em expansão. A caça profissional foi proibida em 1967, afetando muitos Guató que dependiam do comércio de couro para sobreviver. Na década de 1980, foi executada a Operação Pantanal - pelo Instituto de Desenvolvimento Florestal, as polícias 
militares dos dois Mato Grossos e da polícia federal - com uma reação estatal violenta aos coureiros. Alguns Guató foram reprimidos na sua atividade produtiva, sem que o governo solucionasse o problema do sustento dos indígenas.

Todos esses processos foram engrenagens regionais que articularam a dissolução das famílias guató. Motivando a dispersão das pessoas por cidades e fazendas próximas, levaram à sua marginalização e à perda dos contextos em que a língua guató pudesse ser utilizada. Hoje em dia, com duas Tls reconhecidas oficialmente, os Guató voltaram a dispor de espaços em que a língua indígena pode ser introduzida, mas isso dependerá de iniciativas de revitalização bem planejadas e efetuadas.

\section{REFERÊNCIAS}

AZANHA, Gilberto. Relatório Guató, Processo FUNAI/BSB/4683/77, 1991.

BALYKOVA, Kristina; GODOY, Gustavo. Guató: Mani gotođ̧ókwế maegúhi mani gévú (O guaribão pegou uma mulher). Linguística, v. 15, n. 1, p. 271-302, 2019.

CARDOSO, Paulo Alves. Relatório de viagem do antropólogo Paulo Alves Cardoso à área indígena guató, Processo FUNAI/BSB/4683/77, 1985.

CASTELNAU, Francis de Laporte de. Expedição às regiões centrais da América do Sul - Tomo Il. São Paulo: Companhia Editora Nacional, 1949.

CREVELS, Mily; MUYSKEN, Pieter (eds.). Lenguas de Bolivia. Tomo I: Ámbito andino. La Paz: Plural editores, 2009.

CRUVINEL, Noraldino Vieira. Relatório da viagem aos Guatós, Processo FUNAI/BSB/4683/77, 1978.

FERREIRA, Joaquim Alves. Notícia sobre os índios de Mato Grosso. In: AYALA, S. Cardoso; SIMON Feliciano (orgs.). Álbum Gráfico do Estado de Mato Grosso, Tomo I. Campo Grande: Instituto Histórico e Geográfico de Mato Grosso do Sul, 2011 [1848], p. 179-200.

FRANCHETTO, Bruna; GODOY, Gustavo. Primeiros passos da revitalização da língua guató: uma etnografia. LinguíStica, v. 13, n. 1, p. 281-302, 2017.

FREITAS, Júlio César Pereira de. Seres da margem. São Paulo: Baraúna, 2010.

KOSLOWSKY, Julio. Tres semanas entre los indios Guatós: Excursión evectuada en 1894. Revista Del Museo de La Plata, v. 6, p. 221-250, 1895

MONOYER, E. Les Indiens Guatos du Matto-Grosso. Journal de La Société Des Américanistes, Nouvelle Série, v. 2, p. $155-158,1905$.

NETO, José Gondim Lins; GUTMAN, César R. S.; PEREIRA, Luiz Rogério. Relatório do deslocamento à região habitada pelos índios Guató, Processo FUNAl/BSB/4683/77, 1991.

PALÁCIO, Adair Pimentel. Os Guató. Comunicação apresentada na XI Reunião da Associação Brasileira de Antropologia, Recife, 1978.

PALÁCIO, Adair Pimentel. Guató: a língua dos índios canoeiros do rio Paraguai. 155 f. Tese (Doutorado em Linguística) - Instituto de Estudos da Linguagem, Universidade Estadual de Campinas, Campinas, 1984.

SCHMIDT, Max. Indianerstudien in Zentralbrasilien. Berlim: Dietrich Reimer, 1905.

SCHMIDT, Max. Reisen in Matto Grosso im Jahre 1910. Zeitschrift Für Ethnologie, v. 44, p. 130-174, 1912. 